Journal of Teacher Education for Sustainability, vol. 21, no. 2, pp. 73-90, 2019

\title{
Relationship between Proactivity and Personal Pedagogical Knowledge in ESD among Pre-service Teachers: Sub-sampling on Social Media Usage and Subject Discipline
}

\author{
Athira Chellamma Gopalakrishnan and Suresh Bhaskaran \\ University of Kerala, Kerala, India \\ Sudharma Ambujakshi \\ Mahatma Gandhi University, Kerala, India
}

\begin{abstract}
Personal Pedagogical Knowledge (PPK), one of the elementary factors of Pedagogical Content Knowledge (PCK), explains how teacher personality influences his/her unique way of teaching. It is an inevitable part of the Education for Sustainable Development (ESD). Pre-service teachers, who are participating in the knowledge management program for sustainable development, should possess strengthened or organized PPK. The curriculum of Teacher Education should have been reconfigured to conceptualize PPK as a lens to observe various teaching competences needed for sustainability. The personality of a teacher is considered right only when he/she organizes his/her behavior in a proactive way. It means the teacher should develop an ability to be in patience on the right path even though the situation is unfavorable. Proactivity organizes PPK that means the teacher personality is strong enough to make gradual changes in the unfavorable situation and turn it into favorable. This study aims at examining the relationship between Proactivity and PPK among pre-service teachers based on their social media usage and subject discipline in the context of ESD. The major objectives are as follows: (1) to find out the extent of Proactivity and PPK among pre-service teachers in the context of ESD and (2) to find out the relationship between Proactivity and PPK among pre-service teachers. The study adopted a normative survey method by sampling 60 pre-service teachers from science and arts/humanities discipline. The sample is also categorized based on whether the pre-service teachers are users or not users of social media for propagating sustainability. Major findings are as follows: (1) there are significant pairwise differences in the Proactivity and PPK scores of high, average and low levels in the context of sustainability among pre-service teachers; (2) pre-service teachers using social media and those from arts/humanities discipline are exhibiting high levels of Proactivity and PPK than those who are not using social media and those from Science Education; and (3) there is a substantial relationship between Proactivity and PPK among pre-service
\end{abstract}


teachers in whole and relevant sub-samples based on social media usage and subjectdiscipline regarding ESD.

Key words: Education for Sustainable Development (ESD), pedagogical method, Personal Pedagogical Knowledge (PPK), pre-service teachers, proactivity, teacher education for sustainability, social media

\section{Introduction}

The transition from enigmatic situation to sustainability requires profound and radical changes in the beliefs, values, and patterns of social behavior, management regimes, and motivational governance in certain societies (Westley et al., 2011; SalasZapata, Rios-Osorio, \& Cardona-Arias, 2018). When the curriculum of Teacher Education is reconfigured for sustainability, the process of teaching will be more meaningful (Salìte, 2008; Salīte, 2015; Salìte, Drelinga, Iliško, Oḷehnoviča, \& Zarina, 2016).

The teacher, who fine-tunes student cognition for sustainability and spreads his personal aura on student personality, is considered an advocate of renewability. She/he elicits, modifies and ignites every unique passion of child and thereby determines their life chances in a conceivable society. Reading heart, learning soul, advanced knowledge pinpointed brain and love reflecting deeds determine a teacher as a seeker for sustainability. The personal cohesive pedagogical system is gradually developed around such a teacher who identifies him/herself as an exponent of "development that meets the needs of the present without compromising the ability of future generations to meet their own needs" (Brundtland Commission, 1987). The institutionalization of sustainability is possible: (1) if sustainability is progressively integrated with the school governance culture (Salvioni \& Cassano, 2017) and (2) if the performance management feasibly refrains with direct interference of Teacher Proactivity and Personal Pedagogical Knowledge (PPK).

Veritably, PPK and Proactivity are two must qualities of a teacher where the first is the ability to organize Pedagogical Knowledge in connection with one's own personal opinions, attitudes, experiences, thoughts, dreams, etc. and the other reflects a stable disposition behind personal initiative in organizing goal-oriented performance (Seibert, Kraimer, \& Crant, 2001; Li, Wang, Gao, \& You, 2015). It means, when PPK tailors the aim of sustainability, Proactivity does its path.

Among three teaching styles: aggressive, passive and proactive, the far-reaching style is the proactive teaching style that strengthens PPK. In the PPK maturation process, pre-service teachers become assertive and confident to procreate a learning niche, which makes the pupils feel safe, secure and liked. As a result, a teacher values unambiguous directions, friendly communications and appropriate actions to reassure students' confidence and potentialities. Proactivity always stands for "no need to shout" to maneuver the desired behavioral changes within a given learning niche, even though the teacher is so sensitive to every fluctuations and stimulus created within it (Wright, 2005). It means PPK whistles for two challenges: (1) proactive processing of need satisfaction among students and (2) maintaining proactivity in demand-supply routes of the given learning niche. In fact, PPK is both a theory (Ojanen, 1993) and a process of "becoming a teacher" (Handal, 1990). Since Proactivity and PPK are beyond content or structure but more related to teacher personal experiences, it is hypothesized that the rate of change of Teacher - Proactivity causes an equivalent change in Teacher PPK. 
PPK is the product of two constructs: conceptual knowledge and meta-cognitive knowledge (Ojanen, 1993), which are the basic requirements for teaching sustainability and product of two pedagogical philosophies: social behaviorism and experientialism (Zeidler, 2013) that bring out distinctive determinants of sustainable development such as accountability, responsibility, autonomy and dependence. In turn, Garay, Font \& Pereira-Moliner (2017) elucidate Proactivity as the major component of sustainability behavior. Thus, teacher education for sustainability is the training to 'become a gyroscopic compass', i.e., a teacher has to spin through three capacities within/outside classroom: (1) practicing sustainability as hidden curriculum; (2) proceeding proactively and (3) influencing the society.

Education for sustainability catalyzes proactivity and personal pedagogy of preservice teachers when they are exposed to social variables and multi-disciplines. It enhances the rhythmic assimilation of the harmonic homeostatic concept called sustainability within the schema of personal practical knowledge of pre-service teachers (Fedosejeva, Boče, Romanova, Iliško, \& Ivanova, 2018). To make a survey study within and out of such a natural experimental condition, the authors collected samples from both groups of pre-service teachers who actively used social media and group of pre-service teachers who did not use social media. Samples were included from both arts/humanities discipline and science discipline. The study was sub-sampled on two categorical variables: social media usage and subject discipline since they were propagating sustainability and encouraging mass education through setting web-based, open platforms for knowledge management.

According to Hamid et al. (2017), social media enhances the interest of students and staff on environmental sustainability issues. They summarized, "Higher education needs to fully leverage the ubiquity of social media to extend how environmental sustainability is viewed by the students and staff". Sustainability education also has to mesh with certain disciplines such as architecture, engineering, business studies, etc. With reference to Veisson and Kabaday (2018), different disciplines are to be engaged to raise the quality of education, professionalism, and awareness of sustainable development among teachers. These disciplines set forth professional guidelines to provide real world experience through coops, internships, client projects, etc. (Hedden et al., 2017). Since Teacher Proactivity and teaching for sustainability consequently grow through social dispositions and humanitarian contents, the effect of various subject disciplines and habit of social media usage among pre-service teachers have to be taken into account for selecting sub-samples that are convenient for the survey.

Thus, the study attempts to analyze the relationship between Proactivity and Personal Pedagogical Knowledge as the core deducted elements in the context of Education for Sustainable Development (ESD) among pre-service teachers based on social media usage and subject discipline. All hitherto existing literature has shown that the relationship among Teacher Proactivity, Teacher Personal Pedagogical Knowledge and ESD has not yet been clarified on the basis of social media usage and varied subject disciplines. Thus, it is not obvious which one is dominant in a scientific perspective. In such a present scenario, the problem has been undertaken and it is stated as: "Relationship between Proactivity and Personal Pedagogical Knowledge in ESD among Pre-service Teachers: Sub-sampling on Social Media Usage and Subject Discipline”. 


\section{Key Terms}

Proactivity: It is the freedom to choose between stimulus and response that depends on four factors: (1) Self-awareness, (2) Imagination, (3) Consciousness and (4) Independent will (Covey, 2004). In the present study, the concept of Proactivity is defined in the context of Teacher Education for sustainability.

Personal Pedagogical Knowledge: It is the concept that arises out of teacher personal experiences, beliefs, attitudes, and patterns, where experiences fine-tune to learning (Handal, 1990). The present study operationally defines PPK as Personal Knowledge of a teacher on the pedagogical transaction of sustainability.

Education for Sustainable Development: ESD is a means to provide people with the practical skills that will enable them to: continue learning after they leave school, to find a sustainable livelihood, and to live sustainable lives. ESD pedagogies encourage critical thinking, social critique, and analyses of local contexts (UNESCO, 2012; Salìte, Gedžūne, \& Gedžūne, 2009).

Pre-service Teachers: Pre-service teachers are student teachers involved in teaching practice under the guidance of a teacher educator and a subject expert during the internship period of the Teacher Education program.

Social Media Usage: It is the frequent behavior of using open platforms of webbased social media in order to know, comment, like and share the individual opinion on social issues and creativity. In the present study, the authors deal with it as a sub-sampling variable in the context of Teacher Education for sustainability.

Subject Discipline: It can be operationally defined as the core subject and it is an impressionistic and emancipator discipline, in which a pre-service teacher gets trained. In the present study, the authors deal with it as a sub-sampling variable in the context of Teacher Education for sustainability.

\section{Need and Significance}

Education for Sustainable Development is a need more than a passion. Transacting such a passion is a process of reorganizing the curriculum of Teacher Education and enhancing proactivity oriented personal pedagogy among pre-service teachers to ensure sustainability. Personal Pedagogical Knowledge, one of the structural elements of Pedagogical Constructions (PCs) in Pedagogical Content Knowledge (PCK) deals with the influence of teacher's attitude, interest and opinion on the content transaction. Since transacting PPK is a key process in teacher education for sustainability, it should be the hidden curriculum within any content or any discipline. According to Ichinose (2017), preparing ESD calendars, cross-curricular approach, learner-centered learning, planning collaborative lessons, critical thinking, democratic decision making, transformational learning, making behavioral changes, studying local ESD, doing international comparative studies, etc. are effective strategies for bringing trend-setting changes in Teacher Education Curriculum. There are only two rules in teaching sustainability: to begin with it and to continue on it. For this purpose, collecting, creating and sharing knowledge on sustainable development are important. It is supposed that Teacher Proactivity is the tactical connection of the teacher's ethical response with any content to be transacted.

The need and significance of the present study lie in reconfiguring Teacher Education Curriculum with the development and implementation of strategies for enhancing PPK 
and proactivity among pre-service teachers. Such a reconfigured Teacher Education Curriculum has broader ranges of scopes in a technologically developing society. Today's changing society needs a teacher who: (1) changes his/her teaching from a transactional level to a transformational level; (2) is suitable for inclusive Education; (3) adopts the best and new practices; (4) fosters conceptual thinking; (4) is efficient in extraordinary teaching and (5) has thorough knowledge on metacognitive ways of teaching. Pre-service teacher training for sustainability should satisfy all these five needs. In the majority of developing countries, teachers enter the profession after completing the preferred generic qualification. The credibility of teacher recruitment through public service examinations is questionable in the case of maintaining the concept of teaching for sustainability. The process of teacher selection should include an assessment of character motivation and professional aptitude (Amin \& Greenwood, 2019). In this scenario, based on the metaanalysis of related relevant studies, the authors have formulated the following research questions:

1. Do prevailing curricula of Teacher Education for sustainability lack strategies for enhancing Teacher Personal Pedagogical Knowledge and Teacher Proactivity?

2. What is the most significant effect of Teacher Personal Pedagogical Knowledge (TPPK) and Teacher Proactivity within the sustainability culture of classroom?

3. What differences should occur in the TPPK, Teacher Proactivity and teaching for sustainability according to the variations in the social media usage and varied subject disciplines?

4. How do active social media users differ from inactive users in terms of TPPK, Teacher Proactivity and teaching for sustainability among pre-service teachers?

5. How do pre-service teachers belonging to science subjects differ from those who belong to humanities/arts subjects in terms of TPPK, Teacher Proactivity and teaching for sustainability?

For more than 30 years, researchers have been inquiring about the knowledge unique to teaching (specific content to be taught) as professional knowledge. In the 1980s, Lee Shulman and Crew put forth the term "Pedagogical Content Knowledge", which stands for a new domain for Teacher Education. It is defined as one among the seven categories of knowledge pertaining to teaching and they are as follows: (1) General pedagogical knowledge; (2) Knowledge of learner characteristics; (3) Knowledge of educational contexts; (4) Knowledge of educational ends, purposes, and values: philosophical and historical grounds; (5) Content knowledge; (6) Curriculum knowledge on "tools of the trade" for teachers; and (7) Pedagogical content knowledge (Shulman, 1987).

Analysis of the history of Pedagogical Content Knowledge reveals a partially configured snapshot of PCK and defines its basic constructs (Hashweh, 2005). PCK is a collection of basic units called Teacher Pedagogical Constructions (TPCs or PCs) and they should ideally be labeled in multiple interesting ways that connect them to other categories and subcategories of Teacher Knowledge and beliefs. The paper breaks through Pedagogical Constructions that can be reviewed as the idiosyncratic PCKs pertained to a topic and to a pedagogue. 


\section{Teacher Education for Sustainability Propagated through Social Media and Subject Disciplines}

The primary purpose of Teacher Education for sustainability is to educate and train enough teachers to propagate the idea of sustainability to all over the world that is "to create Sustainability Prophets". The review on related studies evidences the scope of such "Creations" in Teacher Education. Tomas, Girgenti and Jackson (2017) studied attitudes of pre-service teachers towards teaching for sustainability. The study revealed that attitude towards sustainability influences skill for pedagogical practice. In another study, Wolff, Sjöblom, Hofman-Bergholm, and Palmberg (2017) implemented policy documents and research recommendations on sustainability among teacher educators to improve university strategies and primary school Teacher Education programs.

Among recent literature, the studies seemed to be very promising are as follows: Young people's conversations about environmental and sustainability issues in social media and their educational implications. It has been found that conversations are argumentative, sophisticated, elaborative and competitive. They create an educational situation (Andersson \& Ohman, 2015). This can be implemented among the Teacher Education field. Klosterman, Sadler, and Brown (2011) discuss the way science educators and researchers advance a teaching and learning agenda for encouraging instruction that more fully utilizes the potential of mass media to explore socio-scientific issues in line with perspectives from education for sustainability. Shepherd and Skrabut (2011) identified several e-portfolio challenges to promote principles of personal learning environments among teachers.

Evans, Stevenson, Lasen, Ferreira, and Davis (2017) have developed taxonomy of four distinctive approaches in Teacher Education for sustainability: (1) embedding sustainability education widely across curriculum areas, courses, and institution; (2) through a dedicated core/compulsory subject; (3) through a component of a core/compulsory subject; and (4) through a dedicated elective subject. Rasmussen (2017) provides an insight into the processes of developing interdisciplinary Teacher Education by framing an institutional perspective on the topic of sustainability in order to analyze how this 'idea' enters science Teacher Education through an interdisciplinary approach. The study identifies sustainability influences among the disciplines as well as disciplinary differences and the findings reveal how sustainability as a teaching topic can be a unifying idea in an interdisciplinary setting. Paige (2016) studied environmental pledges as part of tertiary pedagogical practice in science Teacher Education by focusing on pre-service teachers who have selected a minor in science and mathematics. Participatory and inclusive learning processes, trans-disciplinary collaborations, experiential learning, and the use of the local environment and community are selected as learning resources. Another major finding was provided in the study by Andic and Vorkapic (2017). They proved that a country was a major determinant of awareness and responsibility for sustainability problems. They put forth the need for conducting interdisciplinary and cross-cultural research on personal norms and sustainable behavior. Regarding cultural sustainability, Handayani, Wilujeng, and Prasetyo (2018) explain that elaborating indigenous knowledge in the science classroom is the potential for building meaningful learning and connecting the gap in science education. 


\section{Objectives of the Study}

1. To find out the Proactivity of pre-service teachers in the context of ESD based on social media usage (user and not a user) and subject discipline (arts/humanities and science education).

2. To assess the Personal Pedagogical Knowledge of pre-service teachers in the context of ESD based on social media usage (user and not a user) and subject discipline (arts/humanities and science education).

3. To assess the relationship between Proactivity and Personal Pedagogical Knowledge Creation among pre-service teachers in the context of ESD based on social media usage (user and not a user) and subject discipline (arts/humanities and science education).

\section{Method of the Study}

A multi-stage process of research included: (1) Preliminary documentation analysis on literature related to PPK and Proactivity in the context of Teacher Education for sustainability; (2) Normative Survey method to collect primary data as numerical scores on PPK and Proactivity in the context of ESD among pre-service teachers in the whole sample and the following two sets of sub-samples classified based on: (1) Social Media Usage: social media using and not using; (2) subject discipline: arts/humanities and science education.

\section{Sampling}

A stratified random sampling method was used to collect data. A total sample of 60 pre-service teachers was randomly selected from four strata such as (1) pre-service teachers belonging to arts/humanities discipline; 2) pre-service teachers belonging to the discipline of science education; (3) pre-service teachers using social media; (4) preservice teachers not using social media, according to the sample plan shown in Table 1. Samples were selected from various colleges of teacher education located in Kerala, India.

Table 1

Sample Plan for Selecting 60 Pre-service Teachers for Quantitative Data Collection and Analysis

\begin{tabular}{lcc}
\hline \multirow{2}{*}{$\begin{array}{c}\text { On the basis of discipline to which } \\
\text { pre-service teachers belong }\end{array}$} & \multicolumn{2}{c}{ On the basis of active use of social media } \\
\cline { 2 - 3 } 1. Arts/humanities & $\begin{array}{c}\text { Pre-service teachers } \\
\text { using social media }\end{array}$ & $\begin{array}{c}\text { Pre-service teachers who } \\
\text { are not using social media }\end{array}$ \\
\hline 2. Science education & 17 & 13 \\
\hline
\end{tabular}

The tools and techniques mainly used were as follows: (1) PPK rating scale used to score Personal Pedagogical Knowledge and (2) the proactivity rating scale used to quantify Proactivity. A tool kit containing these two sets of tools was prepared and standardized by the authors of the study. These sets were standardized by checking their reliability and validity using the split-half method and expert evaluation, respectively. Critical 
Ratio, Pearson's coefficient of Correlation (Product-Moment Correlation), T-test and Analysis of Variance were used to treat the numerical measures of two qualitative variables, PPK and proactivity on the basis of social media usage and subject discipline.

\section{Procedure}

The study was carried out in a sample of 60 pre-service teachers selected from various colleges of teacher education located in Kerala, India, during the period of 6 months. The sample was treated with repeated surveys at an interval of two months three times in a row using PPK rating scale and Proactivity rating scale. The quantified values of PPK and Proactivity were compared on the basis of social media usage and subject discipline. Based on the concept of critical value, the hypotheses formulated were tested.

\section{Analysis and Interpretation of Data}

\section{Proactivity of Pre-service Teachers in the Context of Sustainability}

Proactivity Level

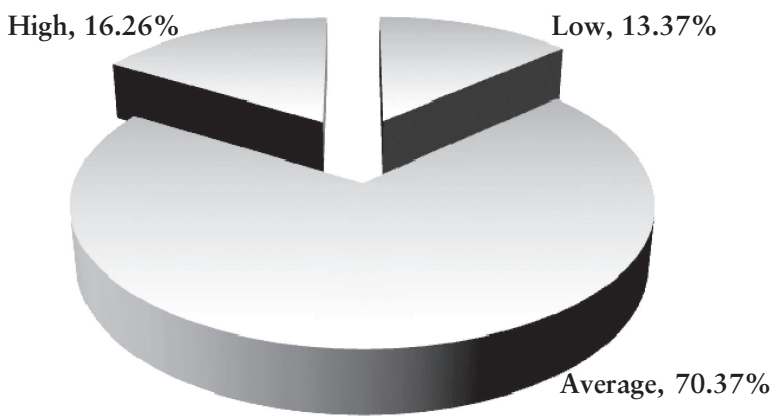

Figure 1. Proactivity of pre-service teachers in percentage for the whole sample

The statistical analysis shows that among 60 pre-service teachers, $13.37 \%$ were found to have a low Proactivity level, $70.37 \%$ belonged to an average level and remaining $16.26 \%$ exhibited a high level of Proactivity in their behavior in the context of sustainability (see Figure 1).

Table 2

The Levels of Proactivity and PPK Scores of Pre-service Teachers

\begin{tabular}{llllll}
\hline & Sources of variance & SS & Df & MS & F \\
\hline \multirow{2}{*}{$\begin{array}{l}\text { ANOVA for the levels } \\
\text { of Proactivity }\end{array}$} & Between groups & 56671.786 & 2 & 28335.893 & \\
\cline { 2 - 5 } & Within groups & 21292.04 & 57 & 373.545 & \multirow{2}{*}{$75.86^{*}$} \\
\cline { 2 - 5 } & Total & 77963.826 & 59 & \\
\hline \multirow{2}{*}{$\begin{array}{l}\text { ANOVA for the levels } \\
\text { of PPK scores }\end{array}$} & Between groups & 100648.38 & 2 & 50324.19 & \\
\cline { 2 - 5 } & Within groups & 32603.048 & 57 & 571.98 & \\
\cline { 2 - 5 } & Total & 133251.05 & 59 & & \\
\hline
\end{tabular}

ANOVA was employed to find out whether there were any differences among these low, average and high level groups of pre-service teachers (shown in the first part of 
Table 2). The calculated $F$ value (75.86 at 2, 57 degrees of freedom), which is more than 0.01 , implies that there is a significant difference of Proactivity in the context of sustainability among the above-mentioned three groups of the whole sample. It means that Proactivity is varied in the range of population, even though the population represents pre-service teachers.

Proactivity in the Context of Sustainability and Social Media Usage

Table 3

The Test of Significance of the Difference between the Overall Proactivity with Respect to the Social Media Usage and Nature of Discipline

\begin{tabular}{|c|c|c|c|c|}
\hline Sub-samples & $\mathrm{N}$ & Mean & $\begin{array}{l}\text { Standard } \\
\text { deviation }\end{array}$ & $\begin{array}{l}\text { Critical } \\
\text { ratio }\end{array}$ \\
\hline Pre-service teachers using social media & 30 & 176.6 & 28.3 & \multirow{2}{*}{$3.8 *$} \\
\hline Pre-service teachers who are not using social media & 30 & 144.7 & 36.4 & \\
\hline Arts/humanities & 30 & 162.30 & 36.6 & \multirow{2}{*}{$0.62 *$} \\
\hline Science education & 30 & 156.6 & 34.9 & \\
\hline
\end{tabular}

$* \mathrm{p}<0.01$

30 out of 60 samples were randomly selected from pre-service teachers using social media and the remaining 30 from pre-service teachers who were not using social media. The responses of both categories are statistically treated separately and a detail of comparative analysis is given in the first part of Table 3 .

\section{Proactivity in Context of Sustainability and Nature of Subject/Discipline}

Critical Ratio 0.62 exceeds 0.01 and it shows that there exists a significant difference between the proactivity in context of sustainability and subject/discipline, where preservice teachers from Arts/ Humanities discipline exhibits high Proactivity level than those from Science Education (Table 3).

PPK of Pre-service Teachers in the Context of Sustainability: In the Case of the Whole Sample

\section{Level of Personal Pedagogical Knowledge}

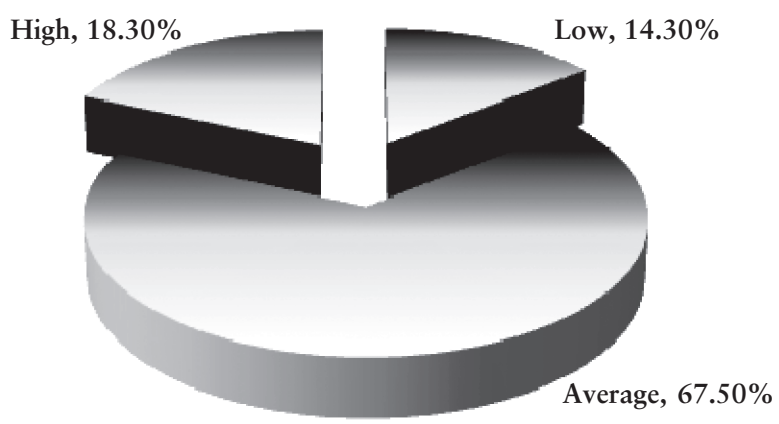

Figure 2. Pie diagram showing PPK of pre-service teachers in percentage for the whole sample 
The statistical analysis showed that among 60 pre-service teachers $14.3 \%$ were found to have a low level of PPK, $67.5 \%$ belonged to an average level and remaining $18.3 \%$ exhibited a high level of PPK. ANOVA was employed to find out whether there were any differences between these low, average and high level groups of pre-service teachers. Details are given in Figure 2.

The calculated $\mathrm{F}$ value (87.98 at 2,57 degrees of freedom) is more than 0.01 . It implies that there is a significant difference in the PPK in the context of sustainability among the above-mentioned three groups of the whole sample (see Table 2). It means that PPK is varied in the range of population, which represents pre-service teachers.

\section{PPK in the Context of Sustainability and Social Media Usage}

Table 4

The Test of Significance Difference between Pre-service Teachers' PPK with Respect to Social Media Usage and Nature of Discipline

\begin{tabular}{lcccc}
\hline \multicolumn{1}{c}{ Sub-samples } & N & Mean & $\begin{array}{c}\text { Standard } \\
\text { deviation }\end{array}$ & $\begin{array}{c}\text { Critical } \\
\text { ratio }\end{array}$ \\
\cline { 1 - 4 } Pre-service teachers using social media & 30 & 463.4 & 47.2 & \multirow{2}{*}{$2.49 *$} \\
\cline { 1 - 4 } Pre-service teachers who are not using social media & 30 & 434.5 & 42.6 & \\
\hline Arts/humanities & 30 & 450.9 & 44.9 & \\
\cline { 1 - 4 } Science education & 30 & 446.3 & 45.7 & \\
\hline
\end{tabular}

$* \mathrm{p}<0.01$

30 out of 60 samples were randomly selected from pre-service teachers using social media and remaining 30 from pre-service teachers who were not using social media. The responses of both categories are statistically treated separately and details of comparative analysis are shown in the first part of Table 4.

\section{PPK in the Context of Sustainability and Nature of Discipline to which Each Pre-service Teacher Belongs}

The total sample was categorized into two groups based on the nature of subject, each of them belongs to. They are art/humanities and science education. Each discipline comprised a sample of 30 pre-service teachers.

Critical Ratio 0.39 exceeds 0.01 and it means that there is a significant difference between PPK in the context of sustainability among pre-service teachers belonging to both selected disciplines such as arts/humanities and science education (shown in Table 4) and it is negligible compared to the fluctuations in PPK within the range of social media usage. Hence, pre-service teachers from arts/humanities discipline exhibit a slight or no increase in PPK compared to those from science education.

To find out the extent of relationship between Proactivity and PPK in the context of sustainability among pre-service teachers, the scores of both Proactivity and PPK were subjected to Carl-Pearson's Product-Moment Correlation; the confidence intervals revealed how significant the given correlations were. The details are given in Table 5. 
Relationship between Proactivity and PPK of Pre-service Teachers: In the Case of the Whole Sample

Table 5

Value, SEr, Confidence Intervals, Shared Variance, $t$ Value and Verbal Interpretations of the Whole and Relevant Sub-samples for the Variable Proactivity and PPK

\begin{tabular}{lccccccc}
\hline \multicolumn{1}{c}{ Sample } & Number & $\begin{array}{c}\mathrm{r} \\
\text { Value }\end{array}$ & $\mathrm{t}$ & Ser & $\begin{array}{c}\text { Confidence } \\
\text { intervals }\end{array}$ & $\begin{array}{c}\text { Shared } \\
\text { variance }\end{array}$ & $\begin{array}{c}\text { Verbal inter- } \\
\text { pretation }\end{array}$ \\
\hline $\begin{array}{l}\text { Pre-service teachers who } \\
\text { are using social media }\end{array}$ & 30 & 0.75 & 19.77 & 0.0252 & 0.65, & 51.12 & $\begin{array}{c}\text { Substantial } \\
\text { correlation }\end{array}$ \\
\hline $\begin{array}{l}\text { Pre-service teachers who } \\
\text { are not using social media }\end{array}$ & 30 & 0.445 & 9.66 & 0.0411 & 0.34, & 19.80 & $\begin{array}{c}\text { Moderate } \\
\text { correlation }\end{array}$ \\
\hline Arts/humanities & 30 & 0.645 & 17.42 & 0.0282 & 0.57, & 41.60 & $\begin{array}{l}\text { Substantial } \\
\text { correlation }\end{array}$ \\
\hline Science education & 30 & 0.745 & 20.16 & 0.0245 & 0.68, & 55.50 & $\begin{array}{l}\text { Substantial } \\
\text { correlation }\end{array}$ \\
\hline Total sample & 60 & 0.671 & 24.84 & 0.019 & 0.62, & 45.02 & Substantial \\
& & & & & 0.72 & & \\
\hline
\end{tabular}

The results show that there is a significant positive substantial relationship between Proactivity and PPK among pre-service teachers in the whole sample. Higher Proactivity in a pre-service teacher will influence PPK and vice versa. Since $r$ value is positive, any change in Proactivity may cause a corresponding change in PPK. The obtained $r$ value has a shared variance of $45.02 \%$ and it suggests that $45 \%$ of variation can be attributed between these two variables.

\section{Relationship between Proactivity and PPK of Pre-service Teachers: In the Case of Relevant Sub-samples}

To find out the extent of relationship between Proactivity and PPK among the subsamples of pre-service teachers, the scores of both Proactivity and PPK of sub-samples were subjected to Carl-Pearson's Product-Moment Correlation; the confidence intervals revealed how significant the given correlations were. The details are given in Table 5 .

The values of coefficient of correlation between Proactivity and PPK for all subsamples are significant at 0.01 level of significance.

In the case of pre-service teachers who are using social media, the result shows that there is a significant substantial relationship between Proactivity and PPK. The relationship shows that there is a considerable dependence of variables on each other. Since obtained $r$ value is positive, any change in Proactivity may cause a corresponding change in PPK and vice-versa. The obtained $\mathrm{r}$ value has a shared variance $51.12 \%$ and it suggests that $51.12 \%$ variation can be attributed between two variables.

In the case of pre-service teachers who are not using social media, the result shows that there is a significant positive moderate relationship between Proactivity and PPK. The relationship shows that there is a considerable dependence of variables on each other. Higher Proactivity of a pre-service teacher will influence PPK. Since obtained $r$ value is positive, any change in Proactivity may cause a corresponding change in PPK and vice-versa. The obtained $r$ value has a shared variance of $19.80 \%$ and it suggests that $19.80 \%$ variation can be attributed between two variables. 
In the case of pre-service teachers from science education, the result shows that there is a significant substantial relationship between Proactivity and PPK. The relationship shows that there is a considerable dependence of variables on each other. Higher Proactivity of a pre-service teacher will influence PPK. Since obtained $r$ value is positive, any change in Proactivity may cause a corresponding change in PPK and vice-versa. The obtained $\mathrm{r}$ value has a shared variance of $55.50 \%$ and it suggests that $55.50 \%$ variation can be attributed between two variables.

In fact, in any case of sub-sampling of the pre-service teachers, the rate of change in Proactivity is directly proportional to the rate of change in PPK and vice-versa. It was also revealed that the pre-service teachers who were using social media and belonging to art/humanities discipline tended to exhibit a high level in both PPK and Proactivity.

There are significant pair wise differences in the Proactivity scores of high, average and low levels in the context of sustainability among pre-service teachers. Pre-service teachers using social media exhibit a high Proactivity level in the context of sustainability than those who are not using social media. In the context of sustainability, pre-service teachers from arts/humanities discipline exhibit a high Proactivity level than those from science education. There are significant pair wise differences in the PPK scores of high, average and low levels among pre-service teachers in the context of sustainability.

\section{Discussion}

The findings of this study report the existence of significant pair wise differences regarding scores of both Proactivity and PPK, i.e., high, average and low levels of Proactivity and PPK are found to occur in the context of sustainability among pre-service teachers. This is because of the existence of three divisions of psychological teaching styles, on which PPK challenges get organized: aggressive, passive and proactive styles (Wright, 2005), where the distinction between proactive and reactive functions of aggression is one of the most common divisions (Rieffe et al., 2016). The responses towards various items in both PPK inventories and Proactivity rating scale on teaching sustainability have shown that high scores, average scores and low scores are gained by preservice teachers who are in proactive, passive and aggressive groups, respectively.

The findings have also shown that Teacher Proactivity for sustainability is found to be expressed much by pre-service teachers who are using social media and belonging to arts/humanities discipline. On the other hand, pre-service teachers who are not using social media and belonging to science discipline are found to be behaving less in a proactive way compared to pre-service teachers who are using social media and belonging to arts/humanities discipline. It may be due to the fact that social media and arts/ humanities discipline comprise more value oriented topics on proactive sustainability. Pre-service teachers who are not using social media and belonging to science discipline lack an open platform to deal with sustainability issues proactively. $\mathrm{Hu}, \mathrm{Gu}$, and Zhang (2017) proved that informational and socializing usage of social media enhanced individual's self-efficacy. Nguyen, Johnson, Collins, and Parker (2016) found out that self-efficacy for specific role behaviors provided capability that modified proactive role behaviors. In the case of arts/humanities education, it is observed that it is not an opportunity for individual's progressive change, but it is an agent of conformity (Higgins, 2017). Conformity is an evidence of individual's internal Proactivity. 
The results of the study have also revealed that social media users show high PPK scores than those who are not using social media. It may be due to the fact that social media enriches not only values on proactive sustainability but also values related to teaching competency. The teachers who actively engage in the knowledge management process of social media express high sociability values of teaching such as courage, technophile nature, efficiency, aspiration, communicative power, sense of humor, empathy, reading etc. and these are more related to Teacher Personality. According to Keating (2017), through social media, the worlds of teacher and student collide. As a result, teacher knowledge on Pedagogical Personality gets matured.

The findings have also revealed that pre-service teachers belonging to arts/humanities discipline show high PPK scores than those belonging to science education, and subject discipline has only a slight influence on PPK compared to the influence of social media. This can be explained by uniqueness of both arts and science disciplines, which represent both humanitarian and scientific values, respectively, in teaching. Arts/humanities represent the affective domain and science represents the knowledge domain. Bloom's taxonomy places the affective domain in a higher order to the knowledge domain. It may be the reason for humanities teachers have shown high PPK compared to science teachers. Szeto and Cheng (2016) found out that the teachers' pedagogical patterns varied depending on various subject cultures and it supported the sixth finding of the present study.

The final finding of the present study is an extrapolation of the summative analytical interpretation of the first and forth findings, i.e., "there is a substantial relationship between Proactivity and PPK in the context of sustainability among pre-service teachers in the whole sample and relevant sub-samples”. In fact, PPK and Proactivity regarding sustainability are directly proportional to each other among pre-service teachers. The teachers showing a high PPK level are critically reflective too and it is interpreted with subjective valuation of CKT (Content Knowledge Test) answers. Some management studies report that professional reflection and Proactivity are growing together factors leading to professional development. According to Messmann and Mulder (2017), "reflection during daily work is a powerful driver for proactive behaviors including innovative work behavior" (p. 141).

If the circle of pedagogical concern and the circle of pedagogical influence of preservice teachers are two concentric circles, either circle of pedagogical influence exists within the circle of pedagogical concern or vice versa (Covey, 2004). Creative usage of social media and training in arts/humanities discipline catalyze the creation of proactive mindset in pre-service teachers. It, in turn, organizes PPK by enlarging the circle of pedagogical influence. It comprises two steps: (1) Enlarging the circle of pedagogical influence than the circle of pedagogical concern and (2) Circle of pedagogical influence diminishes the effect of the circle of pedagogical concern. Pre-service teachers who are not creatively using any type of social platforms and who are not getting an opportunity to deal with arts/humanities discipline will be continuing in the reactive style of teaching. Thus, shuffling of PPK occurs and it shrinks the circle of influence within the circle of concern. 


\section{Conclusions}

The present study reveals the scope of social media and interdisciplinary approach in spreading the influence of Teacher Education for sustainability among teacher trainees. The said variables enhance other two variables such as Proactivity and PPK in the context of sustainability. Pre-service teachers should have to provide an exposure in the knowledge creation process led by social media and they should also be treated with arts/ humanities discipline either in a direct or in an interdisciplinary way.

The social media can act as an open platform for knowledge management and its creative usage provides learning dispositions to pre-service teachers. It generates, manages and shares new ideas, opinions, attitudes, interests, thoughts and dreams. Arts/humanities deal to solve a large range of social issues; they can also create a learning niche of social dispositions to pre-service teachers. Literature review also supports this view by revealing that Proactive behavior is most likely to occur in situations characterized by responsibility, ambiguity and autonomy (Grant \& Ashford, 2008). These characters are central to the professional landscape addressed by many scholars within the career field (e.g., Arthur, Khapova, \& Wilderom, 2005; Sturges, Conway, Guest, \& Liefooghe, 2005) and PPK represents creation of the knowledge in the form of values, beliefs and opinions in the context of sustainability.

Scaife (2012) described the process of 'becoming teacher' as a cycle of three stages such as learning, teaching and surviving. During teacher education program, pre-service teachers are getting trained to be surviving in their classrooms. Ojanen (1993) explained that formation of Personal Pedagogical Knowledge was associated with the process of 'becoming teacher'. Personal Pedagogical Knowledge, the knowledge of personal pedagogical cohesive system, is formed when the systematic reflection of implicit knowledge into explicit knowledge increases. This reflection occurs through the Pedagogic Construction, which acts as a bridge between the outer society and the inner self, otherwise between public knowledge and private knowledge based on the previous works (Ojanen, 1993; Cladinin, 1986; Griffiths \& Tann, 1992; Handal, 1990; Elbaz, 2018).

The present paper empirically proves the existence of a significant relationship between Proactivity and PPK among pre-service teachers, ranging from those who are using social media to those who are not using social media and from the discipline of arts/humanities to the discipline of science education, with an elaborate interpretation. As social atmosphere acts as the stimulus to each teacher's PPK, the PPK itself acts as the stimulus to social climate, in return. Training in Proactivity generates the dedicated teacher community out of any categories of pre-service teachers: average, good and best. A pre-service teacher only needs to have the basic knowledge to train, approach, manage and solve any problem in a proactive way, where Proactivity offers assistance of promises to make personal agents more helpful to their users (Yorke-Smith, Saadati, Myers, \& Morley, 2009). Proactivity is a vital factor to organize Personal Pedagogical Knowledge and social disposition helps implement Proactivity among pre-service teachers. Since Proactivity configures PPK, it matters in Education for Sustainable Development. 


\section{References}

Andersson, E., \& Ohman, J. (2015). Young people's conversations about environmental and sustainability issues in social media. Environmental Education Research, 23(4), 465-485. doi: http://dx.doi.org/10.1080/13504622.2016.1149551

Andic, D., \& Vorkapic, S. T. (2017). Teacher education for sustainability: The awareness and responsibility for sustainability problems. Journal of Teacher Education for Sustainability, 19(2), 121-137.

Arthur, M. B., Khapova, S. N., \& Wilderom, C. P. M. (2005). Career success in a boundaryless career world. Journal of Organizational Behavior, 26, 177-202.

Brundtland Commission. (1987). Our common future: Report of the World Commission on Environment and Development. Retrieved from http://www.un-documents.net/ ocf-02.htm

Burgoyne, N. (2010). Investigating the reliability and construct validity of a measure of preservice teachers' self-efficacy for TPACK. Unpublished Master's Thesis. Brigham Young University, Provo, UT.

Clandinin, D. J. (1986). Classroom practice: Teacher images in action. London: Falmer Press.

Covey, S. R. (2004). The seven habits of highly effective people. ( $2^{\text {nd }}$ ed.). New York: Simon and Schuster.

Elbaz, F. (2018). Teacher Thinking: A Study of Practical Knowledge (2nd ed.). Oxfordshire: Routledge.

Evans, N. S., Stevenson, R. B., Lasen, M., Ferreira, J., \& Davis, J. (2017). Approaches to embedding sustainability in teacher education: A synthesis of the literature. Teaching and Teacher Education, 63, 405-417. doi: https://doi.org/10.1016/j.tate.2017.01.013

Fedosejeva, J., Boče, A., Romanova, M., Iliško, Dz., \& Ivanova, O. (2018). Education for sustainable development: The choice of pedagogical approaches and methods for the implementation of pedagogical tasks in the Anthropocene age. Journal of Teacher Education for Sustainability, 20(1), 157-179.

Garay, L., Font, X., \& Pereira-Moliner, J. (2017). Understanding sustainability behavior: The relationship between information acquisition, proactivity and performance. Tourism Management, 60, 418-429. doi: https://doi.org/10.1016/j.tourman.2016. 12.017

Grant, A. M., \& Ashford, S. J. (2008). The dynamics of proactivity at work. Research in Organizational Behavior, 28, 3-34. Elsevier Ltd. doi: 10.1016/j.riob.2008.04.002

Griffiths, M., \& Tann S., (1992). Using reflective practice to link personal and public theories, Journal of Education for Teaching: International research and pedagogy, 18(1), 69-84. doi: http://dx.doi.org/10.1080/0260747920180107

Hamid, S., Ijab, M. T., Sulaiman, H., Anwar, R. M., \& Norman, A. A. (2017). Social media for environmental sustainability awareness in higher education. International Journal of Sustainability in Higher Education, 18(4), 474-491. doi: http://dx.doi.org/ 10.1108/IJSHE-01-2015-0010

Handal, G. (1990). The concept of rationality in academic science teaching. European Journal of Education: Disciplinary Cultures, 25(3), 319-332.

Handayani, R. D., Wilujeng, I., \& Prasetyo, Z. K. (2018). Elaborating indigenous knowledge in the science curriculum for the cultural sustainability. Journal of Teacher Education for Sustainability, 20(2), 74-88. 
Hashweh, M. H. (2005). Teacher pedagogical constructions: a reconfiguration of pedagogical content knowledge. Teachers and Teaching: theory and practice, 11(3), 27329.

Hedden, M. K., Worthy, R., Akins, E., Slinger-Friedman, V., \& Paul, R. C. (2017). Teaching sustainability using an active learning constructivist approach: Disciplinespecific case studies in higher education. Sustainability, 9(8), 1-18. doi: https://doi. org/10.3390/su9081320

Higgins, L. (2017). The machine society: The current situation for arts in education and the wider society. The STeP Journal: Student Teacher Perspectives, 4(3), 29-33. doi: http://insight.cumbria.ac.uk/id/eprint/3252/

Hu, S., Gu, J., \& Zhang, S. (2017). Social media usage, self-efficacy and cultural intelligence: A longitudinal empirical research in China. WHICEB 2017 Proceedings: Social Media in the Workplace (pp. 261-271). Wuhan, China: AIS eLibrary. Retrieved from http://aisel.aisnet.org/whiceb2017/40

Ichinose, T. (2017). An analysis of transformation of teaching and learning of Japanese schools that significantly addressed education for sustainable development. Journal of Teacher Education for Sustainability, 19(2), 36-50.

Keating, J. (2017). Social media: Do teacher and student worlds collide? Independent Education, 47(2), 30-31.

Klosterman, M. L., Sadler, T. D., \& Brown, J. (2011). Science teachers' use of mass media to address socio-scientific and sustainability issues. Research in Science Education, 42(1), 51-74.

Li, M., Wang, Z., Gao, J., \& You, X. (2015). Proactive personality and job satisfaction: The mediating effects of self-efficacy and work engagement in teachers. Current Psychology, 36(1), 48-55.

Messmann, G., \& Mulder, R. H. (2017). Proactive employees: The relationship between work-related reflection and innovative work behaviour. In Goller, M., \& Paloniemi, S. (Eds.), Agency at work: Professional and practice-based learning (Vol. 20, pp. 141-159). Cham: Springer.

Mishra, P., \& Koehler, M. J. (2006). Technological Pedagogical Content Knowledge: A framework for integrating technology in Teacher Knowledge. Teachers College Record, 108(6), 1017-1054.

Nguyen, H., Johnson, A., Collins, C., \& Parker, S. K. (2016). Confidence matters: Selfefficacy moderates the credit that supervisors give to adaptive and proactive role behaviours. British Journal of Management, 28(2), 315-330. doi: https://doi.org/ 10.1111/1467-8551.12149

Ojanen, S. (1993). A process in which Personal Pedagogical Knowledge is created through the teacher education experience (pp. 1-16). Presented at the International Conference in Teacher Education, Tel Aviv, Israel, June 1993. US: Education Resources Information Center. Retrieved from https://eric.ed.gov/?id=ED398200

Paige, K. (2016). Educating for sustainability: Environmental pledges as part of tertiary pedagogical practice in science teacher education. Asia-Pacific Journal of Teacher Education, 45(3), 285-301. doi: http://dx.doi.org/10.1080/1359866X.2016.1169504

Rasmussen, K. (2017). The emergence and institutional co-determination of sustainability as a teaching topic in interdisciplinary science teacher education. Environmental Education Research, 23(3), 348-364. doi: http://dx.doi.org/10.1080/13504622. 2016. 1182625 
Rieffe, C., Broekhof, E., Kouwenberg, M., Faber, J., Tsutsui, M. M., \& Güroğlu, B. (2016). Disentangling proactive and reactive aggression in children using self-report. European Journal of Developmental Psychology, 13(4), 439-451. doi: http://dx.doi. org/10.1080/17405629.2015.1109506

Salas-Zapata, W. A., Rios-Osorio, L. A., \& Cardona-Arias, J. A. (2018). Knowledge, attitudes and practices of sustainability: Systematic review 1990-2016. Journal of Teacher Education for Sustainability, 20(1), 46-63.

Salite, I. (2008). Educational action research for sustainability: Constructing a vision for the future in teacher education. Journal of Teacher Education for Sustainability, 10(1), 5-16.

Salīte, I., Gedžūne, G., \& Gedžūne, I. (2009). Educational action research for sustainability: Seeking wisdom of insight in teacher education. Journal of Teacher Education for Sustainability, 11(2), 14-30.

Salite, I. (2015). Searching for sustainability in teacher education and educational research: Experiences from the Baltic and Black Sea Circle Consortium for educational research. Discourse and Communication for Sustainable Education, 6(1), 21-29.

Salīte, I., Drelinga, E., Iliško, Dz., Oḷehnoviča, E., \& Zariṇa, S. (2016). Sustainability from the transdisciplinary perspective: An action research strategy for continuing Education Program Development. Journal of Teacher Educational for Sustainability, 18(2), 135-152.

Salvioni, D. M., \& Cassano, R. (2017). School governance, accountability and performance management. International Journal of Financial Research, 8(2), 176181. doi: https://doi.org/10.5430/ijfr.v8n2p176

Scaife, J. (2012). Focus on learning in science. In Wellington, J., \& Ireson, G. (Eds.), Science learning, science teaching (pp. 65-129). Oxfordshire: Routledge.

Seibert, S. E., Kraimer, M. L., \& Crant, J. M. (2001). What do proactive people do? A longitudinal model linking proactive personality and career success. Personnel Psychology, 54, 845-874.

Shepherd, C. E., \& Skrabut, S. (2011). Rethinking electronic portfolios to promote sustainability among teachers. TechTrends, 55(5), 31-38.

Shulman, L. S. (1987). Knowledge and teaching: Foundations of the new reform. Harvard Educational Review, 57, 1-22.

Sturges, J., Conway, N., Guest, D., \& Liefooghe, A. (2005). Managing the career deal: The psychological contract as a framework for understanding career management, organizational commitment and work behavior. Journal of Organizational Behavior, 26, 821-838.

Szeto, E., \& Cheng, A. Y. N. (2016). Pedagogies across subjects: What are preservice teachers' TPACK patterns of integrating technology in practice? Journal of Educational Computing Research, 55(3), 346-373. doi: https://doi.org/10.1177/0735633 116667370

Tomas, L., Girgenti, S., \& Jackson, C. (2017). Pre-service teachers' attitudes toward education for sustainability and its relevance to their learning: Implications for pedagogical practice. Environmental Education Research, 23(3), 324-347.

UNESCO. (2012). Education for Sustainable Development Sourcebook [E-reader Version]. Retrieved from https://sustainabledevelopment.un.org/content/documents/926 unesco9.pdf 
Veisson, M., \& Kabaday, A. (2018). Exploring the preschool teacher's view on professionalism, quality of education and sustainability: International study in Estonia and Turkey. Journal of Teacher Education for Sustainability, 20(2), 5-18. doi: 10.2478/jtes-2018-0011

Wolff, L., Sjöblom, P., Hofman-Bergholm, M., \& Palmberg, I. (2017). High performance education fails in sustainability? A reflection on Finnish primary teacher education. Education Sciences, 7(1), 11-32. doi: 10.3390/educsci7010032

Westley, F., Olsson, P., Folke, C., Homer-Dixon, T., Vredenburg, H., Loorbach, D., \& van der Leeuw, S. (2011). Tipping toward sustainability: Emerging pathways of transformation. AMBIO, 40(7), 762-780.

Wright, D. (2005). There is no need to shout: The primary teacher's guide to successful behavioral management. Cheltenham: Nelson Thornes Ltd.

Yorke-Smith, N., Saadati, S., Myers, K. L., \& Morley, D. N. (2009). Like an intuitive and courteous butler: A proactive personal agent for task management. In Decker, K., Sichman, J. S., Sierra, C., \& Castelfranchi, C. (Eds.), Proceedings of the $8^{\text {th }}$ international conference on autonomous agents and multiagent systems (pp. 337-344). Richland, SC: International Foundation for Autonomous Agents and Multiagent Systems. Retrieved from https://dl.acm.org/citation.cfm?id= 1558059

Zeidler, D. L. (2013). Dancing with maggots and saints: Visions for subject matter knowledge, pedagogical knowledge, and pedagogical content knowledge in science teacher education reform. Journal of Science Teacher Education, 13(1), 27-42.

Correspondence concerning this paper should be addressed to Athira Chellamma Gopalakrishnan, UGC Senior Research Scholar, Government College of Teacher Education, Affiliated to University of Kerala, Thycaud, 695014, ThiruvananthapuramDistrict, Kerala, India. Email: krishnagopaloct30@gmail.com 